\title{
Awareness Versus Production: Probing Students' Antecedent Genre Knowledge ${ }^{1}$
}

\author{
Natasha Artemeva and Janna Fox
}

\begin{abstract}
This article explores the role of students' prior, or antecedent, genre knowledge in relation to their developing disciplinary genre competence by drawing on an illustrative example of an engineering genre-competence assessment. The initial outcomes of this diagnostic assessment suggest that student ability to successfully identify and characterize rhetorical and textual features of a genre does not guarantee their successful writing performance in the genre. Although previous active participation in genre production (writing) seems to have a defining influence on student ability to write in the genre, such participation appears to be a necessary but insufficient precondition for genre competence development. The authors discuss the usefulness of probing student antecedent genre knowledge early in communication courses as a potential source for macrolevel curriculum decisions and microlevel pedagogical adjustments in course design, and they propose directions for future research.
\end{abstract}

Key words: antecedent genre, diagnostic assessment, disciplinary genre, engineering communication, genre awareness, genre competence, New Rhetoric genre theory, prior genre knowledge, rhetorical genre studies, targeted instruction

\section{Résumé}

Cet article explore le rôle de la connaissance antérieure du genre par des étudiants (en ce qui a trait à leur compétence naissante pour reconnaître les genres dans leur discipline) en recourant à l'évaluation de leur compétence à reconnaître les genres en génie. Les premiers résultats de cette évaluation diagnostique suggèrent que la capacité des étudiants à identifier avec succès les caractéristiques rhétoriques et textuelles d'un genre ne garantit pas qu'ils puissent écrire avec succès dans ce genre. Même si une participation active antérieure dans la production d'un genre (écriture) semble avoir une influence sur la capacité des étudiants à écrire dans ce genre, cette participation semble être une condition insuffisante (quoique nécessaire) pour le développement de compétences dans un genre. Les auteurs discutent de l'utilité d'évaluer la

\footnotetext{
${ }^{1}$ Reprinted by Permission of SAGE Publications. Natasha Artemeva and Janna Fox. Journal of Business and Technical Communication, 24 (4), 476-515. (c) 2010 SAGE Publications.
} 
connaissance antérieure d'un genre acquise par les étudiants au début d'un cours en communication pour la prise de décisions macros sur le curriculum et pour des ajustements pédagogiques micros dans la conception de ce cours. Ils proposent ensuite des pistes de recherches futures.

Mots clés : genre antécédent, évaluation diagnostique, genre disciplinaire, communication en génie, conscience d'un genre, compétence dans un genre, théorie du genre propre à la Nouvelle Rhétorique, connaissance de genre antérieure, études rhétoriques de genre, enseignement ciblé

Our stock of knowledge is useful only in so far as it can be brought to bear upon new experience: the new is made familiar through the recognition of relevant similarities: those similarities become constituted as a type. (Miller, 1984/1994, p. 29)

As teachers, we are mostly concerned with how our students fall short, while as researchers, the more we uncover the more awed we are by the complexity and sophistication involved in what we deem commonplace. (Freedman, 1997, p. 179)

When instructors walk into an introductory communication classroom on the first day of class, what should they assume about their students' prior knowledge of disciplinary genres? How could they find out which past experiences may allow students to engage appropriately with communication tasks in a new discipline and which may hinder such engagement? Over the years, questions like these have frequently been raised by our colleagues in an engineering communication program at a Canadian university, which provided the context for this article. Of course, such questions resonate across composition and communication courses, across disciplines, campuses, and countries (e.g., Bawarshi \& Reiff, in press; Ford, 2004; Freedman, 1987; Haas, 1994; Rounsaville, Goldberg, \& Bawarshi, 2008; Wardle, 2007). In this article we begin to address these questions by exploring what students do or do not know at their initial point of engagement with an introductory engineering communication course. This exploration allows us to question our own assumptions about students' prior genre knowledge and to address potential gaps that exist between what we, as communication instructors, assume, and what a classroom-based assessment reveals about student genre competence.

Although the effects of prior knowledge on new learning have been explored in cognitive research on learning and reading (e.g., Dochy, Segers, \& Buehl, 1999; Tobias, 1994) and in studies of transfer (e.g., Ford, 2004; Perkins \& Salomon, n. d.; Tuomi-Gröhn \& Engeström, 2003), issues of prior, or antecedent, genre knowledge have attracted writing researchers' attention much more recently (Bawarshi \& Reiff, in press; Rounsaville, Goldberg, \& Bawarshi, 2008; 
Wardle, 2007). Early research on the effects of antecedent genres conducted by Jamieson $(1973,1975)$ and Jamieson and Campbell (1978) and later furthered by Hoover (1989) provides the foundation for current investigations. Later, drawing on Jamieson's work, Devitt (2004) observed that "the historical evidence suggests that people use familiar genres to act within new situations ... and existing genres serve as powerful antecedents in shaping newly emerging genres" (p. 204).

Currently, researchers from the University of Tennessee and the University of Washington have been conducting a cross-institutional study (UTUW prior genre study, 2007-2008) "to determine what types of genre knowledge student writers enter college with and the extent to which that prior knowledge helps or hinders their abilities to learn new academic discourse conventions" (Bawarshi \& Reiff, in press, p. 114). In this study, the researchers observed that students, when asked to produce a written assignment in a 1st-year writing course, only utilized "genres they associated with school despite their wide genre repertoire" (Rounsaville, Goldberg, \& Bawarshi, 2008, p. 106). These findings suggested that because students in the study assumed that all college genres would be related to the genres they had previously learned at school, they might have ignored other genres that they had acquired outside of school and that "would have been equally if not more useful in completing the assignment" ( $p$. 106).

Although these researchers in Tennessee and Washington were exploring what may transfer from and to 1st-year writing courses, they did not appear to be investigating the role of prior genre knowledge within specific disciplines (Bawarshi \& Reiff, 2009, in press). Other studies of students learning genres at different educational levels have focused on a discipline-specific view (e.g., Ford, 2004; Freedman, 1987; Haas, 1994; Honig, 2010; Russell, 1997; Wardle, 2007), and, although not specifically referring to antecedent genre knowledge, these studies have discussed connections between students' cumulative prior knowledge and their ongoing experiences with or within a discipline over time and in relation to their ability to communicate through the genres of that discipline. Thus, observing primary-school children writing in science classes, Honig (2010) discovered that even though students came "to school expert in many language practices" (p. 88), they experienced difficulties in disciplinespecific classroom discourses.

We begin here with a discussion of the theoretical constructs of antecedent genre knowledge and disciplinary genre competence. We theorize that these constructs define that cluster of ability and experience, that "fuzzy set of literacy practices which are put into play by those who engage in academic work" (Fox, 2001, p. 180), or the stock of knowledge (Miller, 1994; Schutz \& Luckmann, 1973), that students draw from in responding to disciplinary communication tasks. When students initially engage in the discourse of a new discipline, their antecedent genre knowledge may or may not be relevant, and they may or may not be able to draw on it. If this knowledge is relevant, and if 
they can draw on it, then it may ease their transition to the new discipline and further motivate them. On the other hand, if such knowledge hinders their transition to and engagement with the new discipline, it may undermine their confidence and cause them to devalue and marginalize their prior knowledge.

Thus, we consider the usefulness of a diagnostic assessment for subsequent pedagogical actions and interventions in a communication course. Usefulness, according to Bachman and Palmer (1996), is "the most important consideration" (p. 38) in designing assessments. Their consideration of usefulness pertains to assessment qualities (e.g., reliability, construct validity, authenticity, interactiveness, impact, and practicality) that may be used as a "type of metric by which we can evaluate not only the tests that we develop and use, but also all aspects of test development and use" (p. 4). We apply this concept of usefulness in considering the diagnostic genre-competence assessment, which we used to elicit antecedent genre knowledge at the inception of an introductory engineering communication course. Later, we discuss some examples of how this assessment allowed us to develop and implement empirically informed pedagogical actions geared toward individual students' needs.

Throughout, we argue that having a better understanding of our students' antecedent genre knowledge and its role in the development of their disciplinary genre competence will allow us to better support their transition to the discourse of their new discipline (cf. Bawarshi \& Reiff, in press). In other words, such an understanding might help our students to develop the knowledge of how, tacit knowledge (Polanyi, 1997; Ryle, 1949), along with the knowledge of that, explicit knowledge (Artemeva, in press; Geisler, 1994; Polanyi, 1997; Ryle, 1949), even from the very beginning of an introductory course.

Students' development of both types of knowledge may support their success and reduce the chances of failure in their disciplines. As Freedman (1997) pointed out in the framing quote at the beginning of this article, our roles as teachers and researchers may shape to a certain extent how we perceive our students. On the one hand, as teachers, we are often guided by the need to help our students to overcome their difficulties and may thus tend to focus our attention on their lacks and needs -- on how they fall short. On the other hand, as researchers, the more we learn about our students' knowledge and experience, the more we are in awe of the depth, richness, and complexity of that knowledge and experience. As both teachers and researchers, then, we examine in this study the potential of a diagnostic assessment of student antecedent genre knowledge in an engineering communication course. As Bawarshi and Reiff (in press) observe, instructors "can draw on students' prior genre knowledge to inform strategies for teaching students to enter new realms of discourse" (p. 116). Using a diagnostic approach allowed us to move away from our intuitive understandings of what students can and cannot do, and move toward empirically grounded ones; it led to curriculum development, on the macrolevel, and pedagogical adjustments, on the microlevel. The more information teachers have about their students, the more systematic, targeted, 
and appropriate their pedagogical interventions will be (Fox, 2008). We suggest that empirically driven pedagogical actions are inevitably more effective than ad hoc and intuitive ones.

In the following sections, we briefly discuss the constructs of genre and disciplinary genre competence from the rhetorical genre studies (RGS) perspective (Artemeva \& Freedman, 2006; Freedman \& Medway, 1994). Then we examine the construct of antecedent genre knowledge and its relationship to disciplinary genre competence, illustrating how this construct was used in a classroom diagnostic assessment. This hour-long in-class assessment was developed to elicit students' antecedent genre knowledge by probing their ability to recognize a central disciplinary genre and to produce an appropriate text in that genre. Although exploratory in nature, our use of the genre-competence assessment suggests the viability of the construct of antecedent genre knowledge, and the usefulness of such assessment approaches in informing teaching and supporting learning.

\section{Genre and RGS}

In this study, we draw on RGS, also known as North American Genre Theory or New Rhetorical genre theory (Artemeva \& Freedman, 2006; Freedman \& Medway, 1994), which is rooted in Miller's (1984/1994) idea of genre as social action based on "Alfred Schutz's phenomenology" (Russell, 2010, p. 353). This theoretical framework directs researchers' attention to the manner in which "particular discourses are socially motivated, generated, and constrained" (Coe \& Freedman, 1998, p. 137). In other words, RGS highlights what discourses do and helps us to uncover what Hanks (1987) called "the possibilities of meaning" ( $p$. 670).

RGS considers genres as "typified symbolic actions in response to stock sets of situation types" (Artemeva \& Freedman, 2001, p. 166) and emphasizes the dynamic functional reciprocal relation between form and situation (Bawarshi, 2000; Paré \& Smart, 1994). Genres in this view are defined as ever-changing"stabilized-for-now" (Schryer, 1993, p. 200)—communication strategies that arise from and respond to the needs of particular situations. Rather than linguistic "templates" that people acquire, genres are seen as "complex social practices people engage in and transform," (Hengst \& Miller, 1999, p. 325). Because current RGS thinking perceives genres as "typified rhetorical actions and recurrent situations" (Paré \& Smart, 1994, p. 154) and views textual conventions as reflections of underlying regularity, the teaching of genres outside of the specific situations to which they belong is a difficult, if not impossible, enterprise (Freedman, 1993a). The RGS view has stimulated a well-documented discussion about appropriate pedagogical approaches to teaching writing (e.g., Devitt, 2004, 2009; Fahnestock, 1993; Freedman, 1993a, 1993b, 1994, 2006; Hyland, 2007; Williams \& Colomb, 1993), and in recent years, several textbooks based on rhetorical approaches to genre have been published (e.g., Dean, 2008; Devitt, 
Reiff, \& Bawarshi, 2004). But the role of RGS in developing writing and communication pedagogies has not yet been fully explored. Only a handful of studies have attempted to address the potential of this theoretical framework for genre pedagogy and learning (e.g., Artemeva, 2005, 2008, 2009; Artemeva, Logie, \& St. Martin, 1999; Coe, 2002; Devitt, 2004; Freedman, 1993a; 1994; 2006). Drawing on our classroom experience, we explore here how the RGS perspective may lead to new insights about student learning and development and about our teaching. For example, the outcomes of the diagnostic assessment highlight the unevenness and the range of students' prior discursive experiences (Fox \& Hartwick, in press). As Freedman (1997) pointed out, a possible reason for student failure in genre production is lack of experience and engagement with the relevant context:

students already familiar with similar discursive contexts will be at an advantage [in university contexts]. Issues of cultural proximity are thus highlighted, where cultural distance is created by socioeconomic factors, gender differences, minority status, or cross-cultural differences. Some of this may be compensated for by enriching the context further, and by more extensive intervention through collaborative performance by student and instructor. (pp. 189-190)

To actively engage learners we need to systematically probe their prior discursive experiences so that we can provide a rich learning context, moving away from a hit-and-miss approach to one that is targeted and specific (Fox, 2008; Fox \& Hartwick, in press). Before considering our classroom experience, however, we discuss the development of disciplinary genre competence from the RGS perspective.

\section{Disciplinary Genre Competence and RGS}

Some studies have demonstrated that genre learning often occurs gradually without, or with little, explicit instruction, (see, e. g., Freedman, 1987, for a study of 1st-year undergraduates learning to write for a law course, or Wardle, 2007, for a study of the effects of 1st-year composition instruction on students' writing in discipline-specific courses): Freedman's (1987) findings suggested that explicit teaching of the law course genres was unnecessary because students learned how to write for the law course by virtue of participating in the discourses of the discipline. In Wardle's (2007) study, she noted little, if any, transfer of what she called "a writing toolbox" (p. 74) that students were taught in 1st-year composition courses to their disciplinary writing. Rather, their source of learning was discipline specific, and learning to write for a discipline depended, as it did in Freedman's study, on the "courses a student had taken in the field" (p. 81). In other words, such studies have provided evidence that in order to produce texts that are meaningful and recognized as appropriate by a relevant community of practice, a writer needs to be immersed in the practices of a particular community 
(cf. Lave \& Wenger, 1991; Wenger, 1998). As Gee (2008) put it, appropriate texts are both "understandable and acceptable to people who have mastered the domain and are accepted as 'insiders' by others who have mastered" it. He went on to state that it is possible to learn to repeat domain-specific features of messages "without really being able to understand or produce meanings in the domain in a creative way (this often happens in school)" (p. 138) but that to creatively understand and generate appropriate messages requires "embodied experience of action, interaction, and/or dialogue within this domain" (p. 140). This "creative" understanding," or "embodied experience," is what we define here as disciplinary genre competence.

As Artemeva $(2005,2008,2009)$ noted, disciplinary and professional genre knowledge is a result of the accumulated effects of various ingredients that include, but are not limited to, classroom and workplace practices (cf. Berkenkotter \& Huckin, 1995). Or, as Schutz and Luckmann (1973) put it, students' previous experience is "sedimented" and "codified in a stock of knowledge, which acts as a reference ... that individuals use to define new situations" (as cited in Scanlon, Rowling, \& Weber, 2007, p. 226; see also, Russell, 2010). In other words, our uptake (Freadman, 1994, 2002) of what constitutes an appropriate response within a particular communicative context is relational in that it is guided by understandings (albeit typically tacit ones) that arise from our lived experience. These understandings may be seen as a "fuzzy set" (Fox, 2001, p. 180) of knowledge, perceptions, and practices that inform our actions. Thus, novices' increasing competence in meeting the expectations of a new community of practice (Wenger, 1998) develops as a result of their internalizing its conventions through experience. The degree to which they produce appropriate generic responses defines the level of their genre competence (cf. Katz, 1998; Winsor, 1995; Zachry \& Thralls, 2007) -- what Smart and Gilbert (2009) labeled genre capability because the term encompasses not only what is traditionally labeled genre knowledge but also contextualized doing and being. For students entering college, such early stages of genre-competence development includes developing the ability to recognize social situations that correspond to certain genres and then produce texts identifiable as appropriate by the relevant professional or disciplinary readership (cf. Gee, 2008), that is, texts that are rhetorically constructed to meet the expectations of the disciplinary community insiders. To create appropriate texts, students also need to be aware of the appropriate contextualized form of these texts because genre inevitably melds form, substance, and action (Devitt, 2009).

For example, many students who are new to engineering and fresh out of secondary classrooms face a difficult task in distinguishing the social actions that engineering genres perform and their consequent linguistic and rhetorical differences, from those of more familiar genres, such as the genre of the school essay. We acknowledge that a uniform genre of the school essay does not exist and use this term as a necessary simplification. This contrasts, however, with the genre of the engineering technical report. As we have discovered through our decade-long observations of engineers in the workplace and interviews with them 
about their work (e.g., Artemeva, 1998, 2000, 2005, 2008, 2009, in press; Artemeva \& Fox, 1999; Artemeva \& Freedman, 2001), when engineers are asked to write a technical report, they do not inquire, "What kind?" Rather, they ask, "What are the specifics?" In their view and in their words, technical reports are "narrowly defined" and "purpose-driven." That is, our informants indicated that to an engineer, the technical report is a genre, which is never the end in itself but a means to an end (cf. Miller, 1984/1994).

Further, it seems inaccurate to assume that all the students entering our classes arrive with the same kinds of prior genre knowledge; that is, we cannot assume that all students have no prior knowledge of the genre of the technical report just as we cannot assume that all of them are familiar with this genre. Therefore, probing our students' knowledge of genres at the beginning of a course would be most useful in informing our teaching. It would help us to better understand our students' individual needs, so that we can take the appropriate next steps. It might also prompt our students to recognize gaps in their understanding of what constitutes appropriate responses in their engineering communication course. In this context, then, classroom assessment, specifically, diagnostic assessment would be a useful approach.

In the next section, we report on one part of a longitudinal study (Artemeva, 1998, 2000, 2005, 2008, 2009, in press; Freedman \& Artemeva, 1998), conducted in agreement with the policies for ethical research with human participants. We provide an illustration of an assessment strategy-a diagnostic genre-competence assessment-developed to probe students' genre knowledge at the beginning of an introductory course in engineering communication.

\section{An Assessment of Antecedent Genre Knowledge and Genre Competence: An Illustrative Example}

The engineering communication course (Artemeva, 2005, 2008, 2009; Artemeva, Logie, \& St. Martin, 1999) in which our diagnostic assessment is situated was designed in the late 1990s in response to the Canadian Engineering Accreditation Board's requirement to provide intensive instruction in engineering communication as part of the curriculum. This course has been part of the engineering curriculum ever since. In the first months of this course, a recurrent theme in students' postings on the course electronic discussion board was a request to introduce an entrance test at the beginning of the course. The students claimed that the test would "determine what we know already" because many of them thought that they "could be exempted from this class." An example of such an opinion is presented in one student's posting:

I personally was always strong in english and have a really good knowledge of what is currently acceptable and recommended in business writing as well. If we could write sort of an entrance quiz or something, $i$ think they could cut back on the number of students 
in the course and then those that need the help with writing and communication skills could get the attention they need/deserve.

Such comments indicated that a number of students had come into the course convinced that had learned all that they needed to know in secondary school English courses and that their ability to write well in an English course meant that they would be able to communicate well in any context, including engineering. For example, in the preceding posting, the student equates business writing with engineering writing. The student also seems to suggest that such a course is intended for those requiring remedial support.

At the end of the 1st year of teaching the communication course, the instructor realized that she needed to learn early in the term what the students knew and could do in order to tailor the course more effectively to their needs. To compare her own experiences and expectations with those of other experienced technical communication instructors, she circulated a questionnaire asking these instructors for comments regarding their expectations of their students' writing abilities on the first day of class. Nine experienced engineering communication instructors responded. They indicated that they expected their students to be able to "read an academic text and select important information," "explain the meaning/purpose of the text," and "produce traditional academic texts." They expected these texts to be "reasonably grammatically correct," "coherent," "properly paragraphed," "reasonably free of spelling errors," and "more or less free of ambiguities." The instructors unanimously assumed that their students would have "no familiarity" with the genre of the technical report.

Although the instructor understands the difficulties that a transition from high school writing to university-level writing for engineering posed for students, she found this unanimity of these responses somewhat surprising. Intrigued by these experienced communication instructors' conviction that students would not be familiar with the genre of the technical report and concerned with her students' belief that writing skills learned in the high school context would allow them to communicate successfully in any context, the instructor was prompted to develop a no-stakes diagnostic assessment in order to find out what genre knowledge students possessed at the beginning of an engineering communications course.

The instructor administered the assessment at the beginning of the next term to the 62 engineering students enrolled in three sections of the same engineering communication course that she was teaching. The majority of the students were 1st- and 2nd-year engineering students from different streams of engineering, with a few 3rd- and 4th-year students. ${ }^{1}$

The assessment included five passages, all on the same engineering case, the Challenger shuttle disaster (see Appendix A), but each from a different written source that was representative of a particular genre: (passage 1) an encyclopedia entry ("Challenger Shuttle," n. d. a), (passage 2) an academic text (Winsor, 1995, pp. 2-3), (passage 3) a British broadcasting corporation (BBC) 
news Web site (Challenger Shuttle, n. d. b), (passage 4) a technical report (Report of the Presidential Commission on the Space Shuttle Challenger Accident, 1986), and (passage 5) a student essay (Heeks, n. d.). ${ }^{2}$

In responding to the assessment, students were required to complete two connected tasks, a reading task and a writing task. In the reading task, they were asked to read the five passages and identify possible written sources from which such passages might have been extracted. In the writing task, students were required to identify, based on these passages, the issue or issues that needed to be addressed in the case and write what they thought resembled a short technical report on the case. Because insiders within engineering communities of practice clearly recognize the technical report and define it in their own words as "a narrowly defined task" that acts as "part of problem solving", we did not specify the particulars of the technical report that we asked students to write.

The writing task allowed the course instructor to see what types of writing students produced intuitively - based on their interpretation of the five passages, or on their prior knowledge - and to assess their ability to recognize and interpret genres, identify, select, and summarize relevant information, and write a passage in the genre of the technical report. This assessment also gave students firsthand experience with engineering writing, which they might not have encountered before, providing them with an opportunity to see for themselves whether they were proficient users of the technical report genre.

The case-based design of the assessment was informed by Fox's (2000, 2001,2003 ) work in task-based language assessment, which presupposes "that performances elicited by the test will be highly indicative of the use of [language] as a mediating tool in the target domain" (2004b, p. 438). Rather than operationalizing language use in terms of discrete abilities, which may be measured in separable (often underlying) traits or skills, (e.g., by operationalizing reading ability as knowledge of vocabulary, usage, etc.), task-based assessment operationalizes language use as the "dynamic interaction between the situation, the language user and the discourse" (Bachman, 1990, p. 4). Such assessments are designed for the purpose of involving a test taker in the processes and practices within the test, which are as indicative and representative as possible of the processes and practices that are engaged within the "live," or target, domain of performance with which the test taker has limited experience. These assessments elicit situated and socioculturally informed actions.

Drawing on this approach to testing, the assessment provided resources within which the engineering students situated their responses to the assessment tasks; in other words, the assessment itself served to contextualize students' responses to the writing task. By being positioned within an engineering course, the assessment also created an exigence (Miller, 1984/1994) for a clear generic response--a technical report. The assessment design allowed students to obtain the necessary information from the five passages presented in the reading task and use this information to produce a short technical report. To produce a technical report, the students had to modify the way the information was 
presented in the majority of the passages (except the passage from the technical report [Report of the Presidential Commission on the Space Shuttle Challenger Accident, 1986]). That is, the students needed to be able not only to extract the relevant information but also to present it in a way that differed from most of these passages. At the same time, the assessment presented students with a passage from a published technical report that they might choose to use as a model; however, the writing-task instructions did not explicitly direct students' attention to the fact that this passage came from a technical report. It was part of the reading task for them to identify the genre of this passage.

The students' assessment papers were read and commented on by the course instructor, and then, independently, read and assessed by her colleague who teaches in the same engineering communication program. Both of these instructors would be considered engineering communicators and insiders because one of them - the course instructor -- is an engineer with a decade of workplace experience and an experienced technical communicator, and the other has worked in an engineering context, has managed a technical communication consulting firm, and has taught engineering communication.

Students' responses to the reading task were assessed on the accuracy of the source types indicated and on the justifications for these source choices. These responses not only identified the genre of the passages but also offered quasi genre analyses (cf. Artemeva, 2005; Devitt, 2004) that explained the rhetorical purposes of the passages (e.g., "suited to give only the essentials in as little space as possible," "not written for non-technical audience," "no terms explained") and their textual, linguistic, and formatting features. Table 1 lists examples of student responses to the reading task that were assessed as being appropriate.

Table 1. Examples of Appropriate Student Responses to Passages in the Reading Task

\begin{tabular}{|l|l|l|l|}
\hline $\begin{array}{l}\text { Passage } \\
\text { Number and Its } \\
\text { Original Source }\end{array}$ & Student & $\begin{array}{l}\text { Student's Identification } \\
\text { of the Source Genres }\end{array}$ & $\begin{array}{l}\text { Student's Justification for Source } \\
\text { Genre 'identification }\end{array}$ \\
\hline $\begin{array}{l}|l| \\
\text { Entry }\end{array}$ & $\begin{array}{l}\text { Encyclopedia } \\
\text { entudent }\end{array}$ & $\begin{array}{l}\text { "encyclopedia or } \\
\text { specialized } \\
\text { dictionary" }\end{array}$ & $\begin{array}{l}\text { "The text is very brief and to the point. } \\
\text { Covers the start \& finish of the } \\
\text { accident as well as followup. } \\
\text { Informative and very specific with facts } \\
\text { only. No personal interviews etc." }\end{array}$ \\
\cline { 2 - 4 } & $\begin{array}{l}\text { Student } \\
\text { B }\end{array}$ & "Encyclopedia entry" & $\begin{array}{l}\text { "It is a condensed summary of the } \\
\text { incident, similar to a definition of a } \\
\text { word in a dictionary, suited to give only } \\
\text { the essentials in as little space as } \\
\text { possible." }\end{array}$ \\
\hline
\end{tabular}




\begin{tabular}{|c|c|c|c|c|}
\hline & & $\begin{array}{l}\text { Student } \\
\text { C }\end{array}$ & "Encyclopedia" & $\begin{array}{l}\text { "The entry begins with a definition; } \\
\text { sentences are short and formal." }\end{array}$ \\
\hline \multirow[t]{3}{*}{2} & \multirow[t]{3}{*}{$\begin{array}{l}\text { Academic } \\
\text { text }\end{array}$} & $\begin{array}{l}\text { Student } \\
\text { D }\end{array}$ & "academic essay" & $\begin{array}{l}\text { "Seems to be an academic essay } \\
\text { because there are references in the } \\
\text { text that the info. was taken from } \\
\text { another source. Also because the } \\
\text { passage includes a great amount of } \\
\text { detail which indicates that the author } \\
\text { did a significant amount of research." }\end{array}$ \\
\hline & & $\begin{array}{l}\text { Student } \\
\text { E }\end{array}$ & "academic essay" & $\begin{array}{l}\text { "- connecting words, references, etc. } \\
\text { - giving evidence then commenting" }\end{array}$ \\
\hline & & $\begin{array}{l}\text { Student } \\
\text { F }\end{array}$ & "academic essay" & $\begin{array}{l}\text { "- Citation } \\
\text { - Seems to present argument on } \\
\text { proper data analysis" }\end{array}$ \\
\hline \multirow[t]{3}{*}{3} & \multirow[t]{3}{*}{$\begin{array}{l}\text { BBC News } \\
\text { Web site }\end{array}$} & $\begin{array}{l}\text { Student } \\
\text { A }\end{array}$ & $\begin{array}{l}\text { "Magazine or } \\
\text { newspaper" }\end{array}$ & $\begin{array}{l}\text { "format - the article was done in } \\
\text { columns like a magazine/newspaper } \\
\text { article. It is informal with the use of } \\
\text { descriptive emotions like 'fraught eve."' }\end{array}$ \\
\hline & & $\begin{array}{l}\text { Student } \\
\text { D }\end{array}$ & "Magazine" & $\begin{array}{l}\text { "The vocabulary is reader-friendly, } \\
\text { there aren't any difficult technical } \\
\text { terms. Also, the passage is easy to } \\
\text { read and the author set up the } \\
\text { passage in an interesting manner, } \\
\text { which seems like it would be found in a } \\
\text { magazine." }\end{array}$ \\
\hline & & $\begin{array}{l}\text { Student } \\
\text { F }\end{array}$ & “newspaper" & $\begin{array}{l}\text { "Done in small paragraphs (ie. broken } \\
\text { up for easy read), and it quotes an } \\
\text { engineer, which is what newspapers } \\
\text { do" }\end{array}$ \\
\hline
\end{tabular}




\begin{tabular}{|c|c|c|c|c|}
\hline \multirow[t]{3}{*}{4} & \multirow[t]{3}{*}{$\begin{array}{l}\text { Technical } \\
\text { Report }\end{array}$} & $\begin{array}{l}\text { Student } \\
\text { D }\end{array}$ & $\begin{array}{l}\text { "Technical report for } \\
\text { NASA or Morton } \\
\text { Thiokol" }\end{array}$ & $\begin{array}{l}\text { "This passage doesn't have a lot of } \\
\text { detail pertaining to the actual } \\
\text { mechanics of the accident. The } \\
\text { conclusion, however, suggests to me } \\
\text { that the passage was a report } \\
\text { completed to display the findings } \\
\text { concerning the cause of the } \\
\text { Challenger accident. It feels as if the } \\
\text { report would be handed to someone's } \\
\text { boss at NASA or Morton Thiokol, the } 2 \\
\text { companies involved." }\end{array}$ \\
\hline & & $\begin{array}{l}\text { Student } \\
\text { G }\end{array}$ & $\begin{array}{l}\text { "Crash Investigation } \\
\text { Report" }\end{array}$ & $\begin{array}{l}\text { - Plenty of Technical Jargon } \\
\text { - Seems Very Well Researched } \\
\text { - Organization }\end{array}$ \\
\hline & & $\begin{array}{l}\text { Student } \\
\text { C }\end{array}$ & "Technical report" & $\begin{array}{l}\text { "The passage is written in a formal, } \\
\text { dry, technical tone and separated into } \\
\text { sections and subsections" }\end{array}$ \\
\hline \multirow[t]{2}{*}{5} & \multirow[t]{2}{*}{$\begin{array}{l}\text { Student } \\
\text { essay }\end{array}$} & $\begin{array}{l}\text { Student } \\
\mathrm{H}\end{array}$ & $\begin{array}{l}\text { "essay, probably high } \\
\text { school" }\end{array}$ & $\begin{array}{l}\text { "there is an Introduction section clearly } \\
\text { labeled. The sentences are relatively } \\
\text { long and convey a lot of emotion } \\
\text { together with facts. This passage aims } \\
\text { to immerse its audience into the } \\
\text { tragedy of the accident" }\end{array}$ \\
\hline & & $\begin{array}{l}\text { Student } \\
\text { I }\end{array}$ & "high school essay" & $\begin{array}{l}\text { "There is a lot of 'filler' in this } \\
\text { introduction. It contains a lot of } \\
\text { unnecessary information --> things that } \\
\text { high school teachers love to read. } \\
\text { There is a thesis sentence and you } \\
\text { know exactly what the essay will } \\
\text { concern." }\end{array}$ \\
\hline
\end{tabular}

Note: Students' writing is reproduced without change.Students' responses to the writing task were assessed for accuracy of content and appropriateness of organization and rhetorical conventions (including format).

The course instructor provided diagnostic information in the form of written feedback summarizing the strengths and weaknesses of each response to each task. Before the papers were returned in the second class, the students were asked to write their reflections on the assessment (see Appendix B), 
justifying the choices they had made while responding to the writing task. The course instructor collected the students' reflections and compared them with their performances on the assessment. This allowed the instructor to make informed decisions on the next pedagogical steps in the course, for example, assigning students to peer feedback groups, defining different student roles in peer feedback groups, and altering assignment expectations (cf. Rehling, 2010). Later, once the course had ended, the instructor asked students to review their assessment from the first day of class and write another reflection on it.

In considering the role that antecedent genre knowledge played in the students' performance on the diagnostic assessment we drew on the assessment papers, these two reflections, and retrospective interviews with some of the students. In the next two subsections, we present the results of the students' performance on the reading and writing tasks.

\section{Performance on the Reading Task}

We were particularly interested in students' ability to distinguish a technical report passage (passage 4 in Appendix A) from other text types. Of the 62 students who took the assessment, only nine students (14.5\%) incorrectly identified the technical report passage whereas 48 students $(77.4 \%)$ correctly identified the passage as a "technical report," and 5 students (8.1\%) correctly identified features of the passage but identified the source type as a "technical log" or "technical journal" rather than a technical report (see Table 2). We categorized such responses as a slight error in identification. Although the format of the passage might have indicated to the students that the passage was part of a larger technical document, students' justifications for their source choices were not limited to the formatting features.

Similarly, the majority of students were able to correctly (or with a slight error) identify the source types of the other four passages from the reading task. In their justifications for their source choices, the majority of students identified features of the passages (e.g., "there is an Introduction section clearly labeled. The sentences are relatively long and convey a lot of emotion together with facts" for a high school essay or "the entry begins with a definition; sentences are short and formal" for an encyclopedia entry) and explained why the presence of such features justified their source choice (see Table 1) based solely on their previous experiences with the genres. 
Table 2. Comparison of Students' Performances in the Reading and Writing Tasks for

the Technical Report Passage $(n=62)$

\begin{tabular}{|l|l|l|}
\hline $\begin{array}{l}\text { Assessment of Student } \\
\text { Responses in the Reading } \\
\text { Task for the Technical } \\
\text { Report Passage }\end{array}$ & Number of Students & $\begin{array}{l}\text { Number of Students Who } \\
\text { Wrote an Appropriate } \\
\text { Technical Report } \\
\text { Passage }\end{array}$ \\
\hline Incorrect source type & 9 & 0 \\
\hline Slight error in source type & 5 & 0 \\
\hline Correct source type & 48 & 7 \\
\hline
\end{tabular}

\section{Performance on the Writing Task}

In contrast to the students' performance on the reading task, only seven (11.3\%) out of the 62 students wrote passages that both instructors ranked as appropriate (see Table 2). All students who wrote appropriate passages in the writing task had also correctly identified the source type of passage 4 as a technical report in the reading task and provided acceptable justifications of their choices. Six out of these seven students indicated in their reflections on the assessment (see Appendix B for the questions that students were asked to reflect on) that they had had prior exposure to technical reports. The other student who wrote an appropriate technical report passage wrote in his reflection that he had not previously been exposed to technical reports. (This student's passage is shown in Figure 1). But in a later interview, this student described his past work experience in an engineering firm where he had, in fact, written small parts of reports. When asked why he had not indicated this experience in his reflection, the student responded that he had not consciously recognized writing small parts of a report as being "exposed to technical reports" until his attention was drawn to this connection. His behavior is reminiscent of that of one of Wardle's (2007, p. 79) students (also see Ford, 2004). Wardle's student had not been able to recognize similarities in assignments in a 1st -year composition course with those in other courses until Wardle indicated them to her. This inability to recognize similar previous experiences might be one of the reasons why many students are not able to draw on their prior knowledge of relevant genres: Without support that raises their awareness, they are unable to recognize similarities or differences in genres (e.g., students rarely would draw on similarities between science laboratory reports and technical report passages). Teaching genre awareness, as Devitt (2004) suggests, might provide students with such support. 
1.0. Inteduction

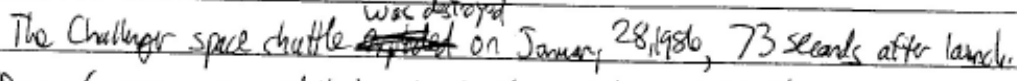

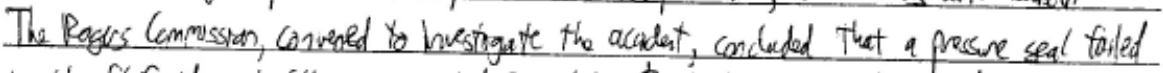

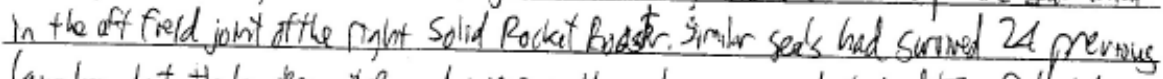

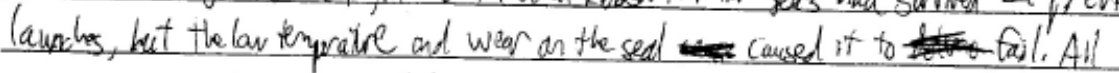

seven crew members wote Hilled.

1.1 Launch sumpory

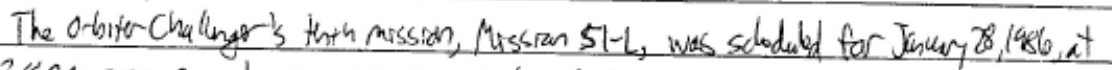

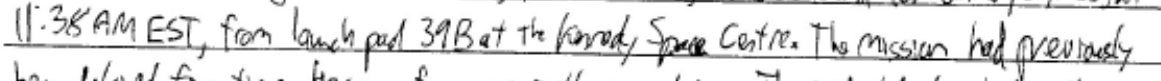

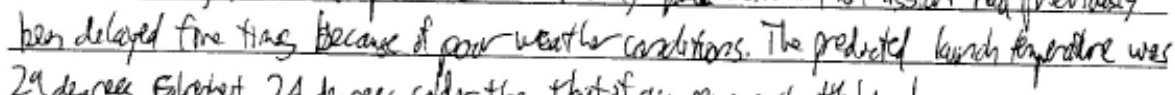

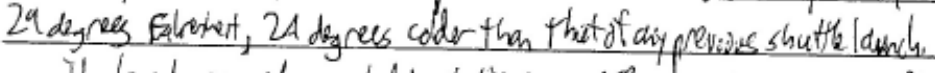

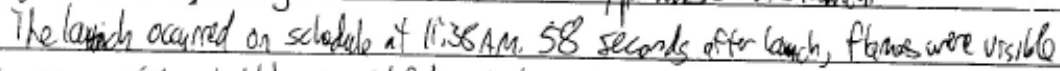

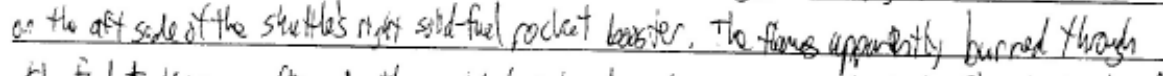

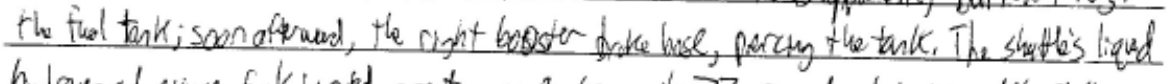

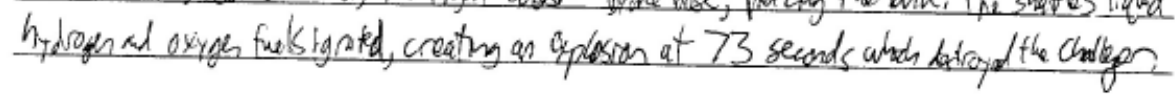

2.0 Comses

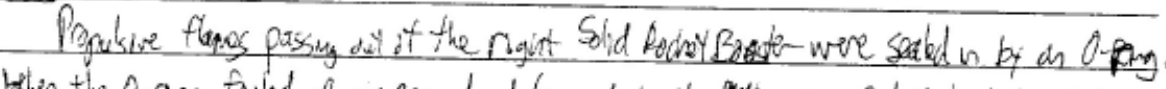

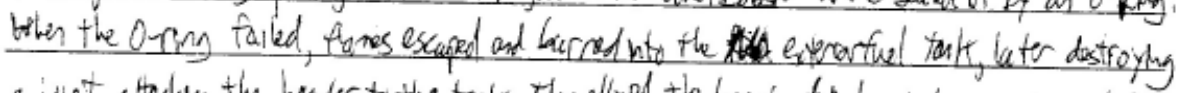

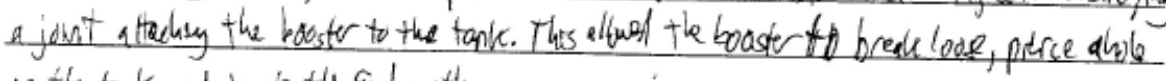
in the tank, ad inaife the fuel withen.

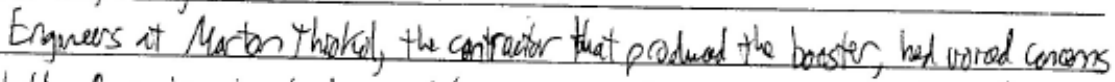

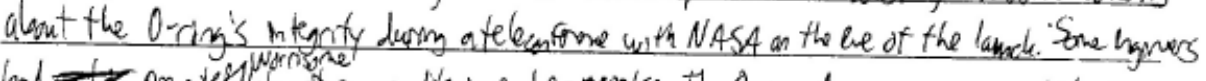

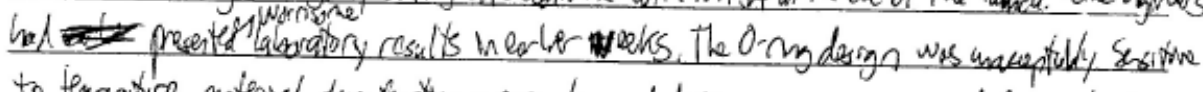

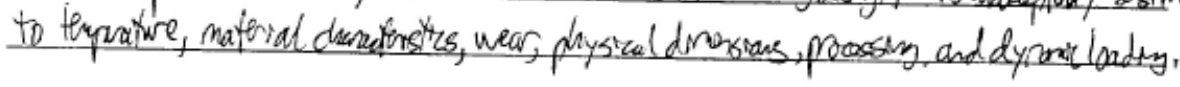

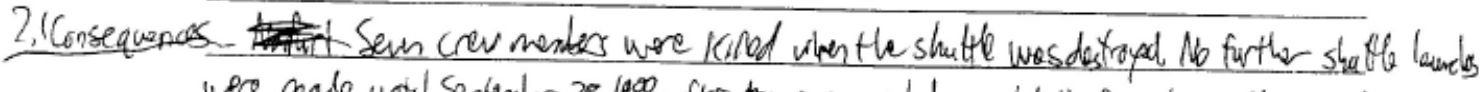

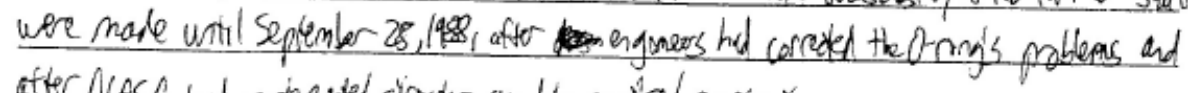

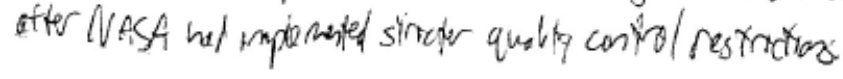

Figure 1. Writing Task: Passage Evaluated by Both Instructors as Appropriate.

Another student in our study wrote in her reflection that she had been exposed to technical reports; however, she had written a typical school essay passage in the writing task. (Her passage is shown in Figure 2). From her further reflections, we could see that her exposure had been limited to compiling research for an engineering professor. She had read the reports but was not involved in writing them. 
Engineess hav many responsabizities in the modern world. Nany lives depend on "good" engineers. There hos been a nomher \& engneering disasters in thie past, eome not-so-se rions and somer batastiodic. One engineoning dis aster which wowed lie in the catastrophic category woned be the Challenger Disaster, which oeceuned on Janwary $28^{4}, 1986$. The Challenger was the $25^{\text {th }}$ space shottle te go vo Space. The problem secmed the lie within the O.RAnes, the two robber rings which sealed yengether segments of the boosters. Ilust moments aiter take off, the O-rings failed, wetting oit Mlames whis consequently piercod the fort tank. a dangerous nixtore of liquid hudrogen and liquad oxygen fiels ignited, causine the sine the to expinde, ox only 73 seconrk whto flighto why did the o-Rincs far? $\rightarrow$ Hany rasens Many facters seem to have been ignored bu the devignein o the o-rings.

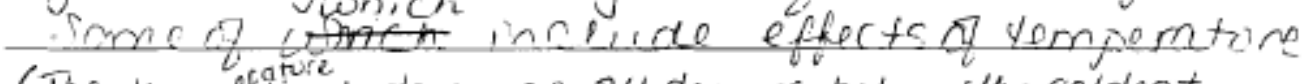
(The tempelithet day was 24 degrees helow the coldest launch todate), physical dimensions and the reaction of the jount te dynamic loading. This whoce catestrophy ceved have keen avorided if the engineers who desianed che O-Rings tested each and

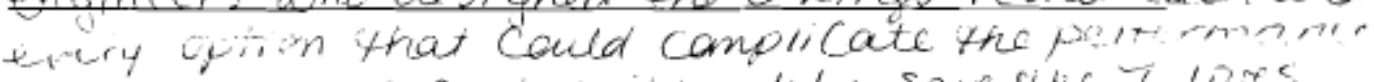
of the u-rings and vitimately save the 7 lives onich were lost.

Figure 2. Writing Task: Passage Evaluated by Both Instructors as a School Essay.

In total, 17 (27.4\%) out of the 62 students claimed that they had had some prior exposure to technical reports. But only 11 of these 17 students commented that they had actually written technical reports, and only seven of these 11 students wrote appropriate passages (see Table 3).

TABLE 3. Effect of Students' Prior Exposure to Technical Reports on Their Writing 
Task Performance $(n=62)$

\begin{tabular}{|l|l|l|}
\hline $\begin{array}{l}\text { Type of Prior Exposure to Technical } \\
\text { Reports }\end{array}$ & Number of Students & $\begin{array}{l}\text { Number of } \\
\text { Students Who } \\
\text { Wrote an } \\
\text { Appropriate } \\
\text { Technical Report } \\
\text { Passage }\end{array}$ \\
\hline No prior exposure & 45 & 0 \\
\hline $\begin{array}{l}\text { Read technical reports but did not } \\
\text { write any }\end{array}$ & 6 & 0 \\
\hline Read and wrote technical reports & 11 & 7 \\
\hline
\end{tabular}

In fact, the majority of students produced traditional school essays, similar to the one reproduced in Figure 2, rather than texts resembling a technical report. These essay-like passages were written in a single paragraph as descriptive narratives containing emotional language and rhetorical questions. A few students attempted to write a one-paragraph summary of the information presented in the reading passages, and a smaller number yet $(11.3 \%)$ wrote passages resembling a technical report (as in Figure 1). These passages were characterized by a logical presentation of information, a thoughtful treatment of new and assumed common knowledge (i. e., they reflected reader awareness by providing a relevant title, description of the event, and discussion of the breakdown in communication between the engineers and NASA, possible causes of the Challenger explosion, its consequences, etc.), an appropriate use of technical vocabulary along with necessary definitions and explanations; and reader cues such as (sometimes numbered) headings and subheadings, paragraphing, or bulleted lists. In other words, these students were able to successfully draw on what Dannels (2009) identified as nuances in relational genre knowledge; that is, understanding the duality of the assessment context as both real and simulated, these students were able to interpret the tensions within this context and produce the expected genre.

At the end of the term, the instructor asked the students to go back and examine their performance on their original assessment papers, which they had kept in their course binders and provide comments on this performance in relation to their understanding of engineering communication now that they had completed the course. The students reviewed their assessments and responded by posting messages to the course's electronic discussion group. Some postings addressed what students thought was at the root of the difficulty that they had experienced with the assessment writing task. Many of them responded with 
comments such as this student's: "Before taking this class, my only writing experience was writing academic essays in high school, never technical documents." Students noted that school essay writing had influenced their writing on the assessment. As one of the students simply put it, "I am used to writing essays." Another student commented, "After overlooking my tests, I realized that I didn't do well on the [Writing] Task . . . . I assumed that technical writing is the same as writing an essay." In summary, students specified that before beginning the engineering communication course, they had usually been expected to produce texts containing long, complex sentences; many adjectives; emotional language; and personal opinions. As one student noted, "This is what a high school teacher expects from you."

At the end of the course, a number of students were clearly cognizant of the central role of reader awareness, which they started to recognize as a defining factor in communication, and its effect on the texts that they produced. From students' responses at the end of the term, we can see how their genre distinctions became clarified and sharpened as their genre competence developed. As one student observed, "I am now aware that good technical form and brevity of the document are instrumental in conveying the information most effectively to the audience." This observation reflected his growing understanding of engineering genres as the "fusion of form, substance and action" (Devitt, 2009, p. 27). Another student noted the following:

I have reviewed my test done on the first day of the class, and I have seen the following changes in my knowledge: my sentences were too long and not clear enough to allow my reader to understand it well without giving special attention or concentration. I also did not know that I had to try to format a technical document . . . to have the document easier to read [so that a reader] could go through without reading everything [i. e., just reading what they needed to].

And yet another student noted, "I've definitely gained an appreciation of the importance of keeping audiences interested in the subject matter of any [italics added] report or presentation."

These student comments are somewhat different from those in Ford's (2004) study, in which engineering students tended to emphasize features of formatting as an important part of what they had learned in a communication course and rarely mentioned such rhetorical strategies as audience awareness. Even though we recognize differences between Ford's study and ours in course designs, assignments, U.S. and Canadian students, teachers, and so on, our use of diagnostic assessment appeared to have contributed to the development of students' ability to focus and reflect on the central role of audience awareness in writing and its effects on rhetorical and linguistic features of engineering texts.

Having highlighted what we learned from this diagnostic assessment about our students' prior genre knowledge, we discuss in the remaining sections 
the theoretical and pedagogical implications of the assessment and reflect on its usefulness (Bachman \& Palmer, 1996).

\section{Discussion and Implications}

Many students did not expect to learn anything new in the engineering communication course because they expected it to be, as one of them wrote, "a pure English course that would teach how to write in proper English structure." And some of them were convinced that their facility with school essays was sufficient for writing any type of text. At the same time, nine experienced engineering communication instructors did not think that on the first day of a new course, their students would be able to distinguish between technical and nontechnical genres or identify generic rhetorical and textual features in reading passages. And these instructors did not expect that students would be able to write in any genres other than traditional academic ones (e.g., school essays).

In contrast, students' performance on the reading task of the diagnostic assessment indicated that almost all of them had developed sensitivity to different genres prior to the communication class and were able to conduct quasi genre analyses of the reading passages--without having ever been taught how to do so and without even realizing that they were doing so (cf. Artemeva, 2005, for a novice engineer's quasi genre analysis of the engineering proposal). At the same time, as the nine instructors had expected, most students were unable to write in the technical report genre. Although the experienced communication instructors' expectations with regard to students' writing were largely met, our observations suggested that there was a meaningful gap between these students' genre sensitivity in reading (and at times, in writing) and the instructors' expectations about their prior genre knowledge.

\section{Theoretical Implications}

Overall, students' awareness of genre differences and their ability to identify and report genre features did not enable them to produce a text in the requested genre. Only 11 students claimed to have had previous experience in writing parts of a technical report, and only seven of those 11 students who claimed that they had had experience writing in that genre performed appropriately on the writing task (which may be attributed to students' misunderstanding of our question or of their previous experiences). This outcome supports Freedman's (1994) contention that "full knowledge [of a genre] . . . only becomes available as a result of having written [in that genre]" (p. 206).

Swain and Lapkin's (1995) hypothesis of pushed output (Fox, 2004a; Swain, 1985; 2000) provides additional support for our observations. Swain and Lapkin claimed that production assists acquisition only when the learner is forced to produce dialogically comprehensible output (i.e., output that can be 
understood by an interlocutor). ${ }^{3}$ They argued that for competence development, comprehensible output is as necessary as comprehensible input. In other words, if learners are pushed to produce comprehensible output, it will force them to focus on both meaning and form. The central claim of Swain and Lapkin's hypothesis of forced, or pushed, output is that " 'pushing' learners beyond their current performance level can lead to enhanced performance, a step which may represent the internalization of new ... knowledge, or the consolidation of existing knowledge" (p. 374)

Therefore, we would argue that situated performance itself is a primary vehicle for genre acquisition (cf. Artemeva, 2005, 2008, 2009; Dias, Freedman, Medway, \& Paré, 1999; Freedman, 1994). Even though the majority of students had developed sufficient genre competence that allowed them to recognize and identify the genre of the technical report passage in the reading task, only those who had participated--even peripherally (cf. Lave \& Wenger, 1991)--in the process of writing such reports in workplace situations were able to perform successfully in the assessment writing task. These observations indicate that although certain types of instructional experiences, such as the diagnostic assessment discussed here, may heighten students' genre awareness and enhance their potential for genre production, they may not ensure it.

Table 1 provides evidence of the accuracy with which students were able to identify rhetorical and linguistic features of the technical report passage (see Appendix A, passage 4). A key finding of the diagnostic assessment is that they were able to do so on the first day of classes without having had any prior instruction on the technical report genre. Student responses to other reading passages demonstrated similar accuracy.

As Freadman (2002) suggested, perhaps what is most important about our knowledge of genres is our knowledge of the differences between genres. Students' ability to identify the features of the reading passages as characteristic of various genres indicates that these students were adept in both distinguishing between genres and articulating the differences between them. Although Devitt (2004) suggested that "students ... draw on known genres to tackle unfamiliar situations" (p. 207), the majority of students in our study were unable to write in the genre of the technical report regardless of whether they had had an opportunity to view and read technical reports prior to coming to the communication classroom; in other words, they were unable to draw on the genre that they had encountered in the past (cf. Bawarshi \& Reiff, in press; UTUW Prior Genre Study, 2007-2008). As Wardle (2007) observed, "simply having had previous experiences similar to the new ... writing task [is] not enough to ensure generalization [from these previous writing experiences]" (p. 80). The discrepancy between our students' ability to recognize the genre in a reading passage without difficulty and their inability to produce a text in this genre reminds us of Bakhtin's (1994/1997, 2004) observation of his secondary school students in Russia. These students had little difficulty understanding a particular sentence structure, ${ }^{4}$ which they had been explicitly taught by their Russian 
language teachers, when they encountered it in a printed text or in a dictation, "but at the same time, ... [they were] completely unable to use this form in their own writing and [could not] work with it creatively [italics added]" (Bakhtin, 2004, p. 16; cf. Gee, 2008) because they did not understand when and why such a structure could be used in "live" discourse. Bakhtin's small study suggests that explicit knowledge may be a necessary but insufficient condition for the development of writing competence.

Our observations also remind us of the work of Jamieson $(1973,1975)$, who investigated the effects of antecedent genres on new emergent ones and demonstrated that "perception of the proper response to an unprecedented rhetorical situation grows not merely from the situation but also from antecedent rhetorical forms. . . Choice of an appropriate antecedent genre guides the rhetor towards a response consonant with situational demands" (1973, p. 163). Even though a sociocultural situation that gives rise to the genre of the technical report is not unprecedented in our society, it can be viewed as such by students who are just entering an engineering program and who have not encountered such a situation. Students in our study, as well as in the University of Tennessee and University of Washington's (Bawarshi \& Reiff, in press; UT-UW Prior Genre Study, 2007-2008) and Wardle's (2007) studies, often relied on inappropriate genres that they had encountered in the past. As Hoover (1989), who further developed Jamieson's ideas, indicated, "the antecedent rhetorical style of a speaker limits [italics added] the choices available [to the speaker] when the rhetorical situation changes and necessitates the use of a new rhetorical response" (p. 250).

This illustrative example of a sample diagnostic assessment provides some initial evidence of how students draw on familiar genres-most often tacitly-when they are asked to enact a new genre. In other words, these students produced texts that, in Jamieson's (1975) words, "bear the chromosomal imprint" (p. 406) of familiar genres - most often, the school essay. In their end-of-term reflections, students observed that they had needed to resort to these familiar ways of writing — school essay writing —on the assessment. They had brought habitual "ways of acting with words" (Russell, 1997, p. 522) from one rhetorical context to another. Assuming that, to paraphrase Gertrude Stein, writing is writing is writing, they fell back on their competence in essay writing.

\section{Pedagogical Implications}

These students brought their habitual ways of writing to the engineering communication classroom only to discover that these ways were inappropriate. Indeed, the assessment itself created the context in which they could make this discovery safely at the beginning of the course. As we showed, some students were eager to take a test to prove that they were already able to communicate in any context. The diagnostic assessment addressed this need; further, by virtue of being an assessment, it engaged their attention - they all wanted to know, "How did I do?"-in a way that another type of classroom activity might not. The 
assessment stimulated their developing sensitivity to genre differences in a safe (because their performance was not tied directly to a mark), or neutral, territory, where they could take full advantage of this learning experience.

The diagnostic assessment assisted the instructor in determining each student's actual developmental level (Vygotsky, 1978, 1935/2003) at the time of the assessment. According to Vygotsky, the actual developmental level is determined by the difficulty of the tasks that students are able to complete alone - that is, in the context of the diagnostic assessment, by how well each student was able to produce an appropriate text in the genre of the technical report when working alone, without support from the instructor or more capable peers. Determining students' actual developmental level, then, is the first step to determining their zones of proximal development (ZPD, Vygotsky, 1978, $1935 / 2003$ ), or the imagined zones between what students are able to do alone and what they can do with the assistance of an instructor or a more capable peer. As Vygotsky (1978) explained, "proximal development characterizes mental development prospectively [italics added]," in other words, the ZPD allows instructors to understand what competence students have already developed and what competence is "in the process of maturing" (p. 87). Understanding students' ZPDs and the difference between their genre competences in reading and writing had important pedagogical implications for the classroom, both at the macrolevel of curricular decisions and at the microlevel of teaching strategies ( $T$. Tachino, personal communication, December 10, 2009). In the next subsection, we provide some examples.

\section{Adjustments at the Macrolevel: Curricular Decisions}

The assessment's usefulness (Bachman \& Palmer, 1996), specifically in relation to its impact, was demonstrated through the evidence it provided of the students' early relative positioning in relation to the course objectives. This evidence, consequently, informed the tailored pedagogical design of the course. In other words, the assessment identified where adjustments needed to be made in the course and how each of the original course components should be modified (Fox, 2008; Fox \& Hartwick, in press). Some key modifications resulting from the assessment included heightened emphases on what makes communication successful, that is, on the contexts of communication in relation to the genre; on differences between inaccurate and accurate assumptions about shared knowledge (cf. Giltrow \& Valiquette, 1994); and on selection and accuracy of technical information.

For example, knowing that only a few students were ready to perform in the genre of the technical report, the instructor devised a series of small incremental assignments that introduced students to an engineering project "genre set" (Devitt, 1991, p. 340) that included the genres of proposal, progress report, and formal oral presentation. These interrelated sequential assignments culminated in the production of the technical completion report. 
The assessment also allowed the instructor to ground her expectations of student performance empirically, before students submitted their first assignments. By probing students' ZPD and understanding the nature of the gap that existed between their actual level of genre competence and the instructor's performance expectations, she was able to modify the pacing of the course accordingly so that she devoted more time to discussions in support of the early assignments. As a result she was far more confident that the context of the course provided essential experience required for students' successful performance.

\section{Adjustments at the Microlevel: Targeted Pedagogy}

To tailor communication courses to the needs of individual students, we need to probe students' genre competence early in the course. Diagnostic assessment provides us with one means to this end. This use of assessment for learning is consonant with the approach that Clarke (1998) recommended:

In order for improvement to take place the [learner] must first know the purpose of the task, then how far this was achieved, and finally be given help in knowing how to move closer towards the desired goal-how to close the gap. (p. 68)

For example, at a time when students were likely to be most receptive, the assessment created an opportunity for the instructor to provide her initial formative feedback to each of them, thus, paving the way to the practice of peer feedback in the course and beyond. As one student observed at the end of the course, "Previous to this [course] . . I I really did not realize the value of feedback ... and how much it affects the final document."

Also, knowing more about each student's actual developmental level (Vygotsky, 1978, 1935/2003) as reflected in their genre competence and about their antecedent genre knowledge early in the term allowed the instructor to match peer groupings with activities that addressed the individual needs of students. She assigned students to peer feedback groups and defined their initial roles (cf. Rehling, 2010) according to their strengths and weaknesses in order to optimize work in each student's ZPD. The seven students who had demonstrated genre competence in writing a technical report passage on the assessment were initially allocated to separate peer feedback groups in the role of peer mentors, thus ensuring that genre expertise was spread across all the groups in the class.

\section{Conclusion}

This article discusses the role of engineering students' antecedent genre knowledge in the development of their relational (cf. Dannels, 2009) genre competence. We have framed this article with questions that have been raised in 
research and by communication instructors in attempting to understand what genre knowledge students bring to communication courses and whether and how this knowledge affects their performance in the dual context (Dannels, 2009) of the engineering writing course taught at universities. We highlighted gaps between instructors' expectations and students' genre competence through the illustrative example of a diagnostic assessment that allowed us to probe students' antecedent genre knowledge and thus get a glimpse of the stock of knowledge (Miller, 1994; Schutz \& Luckmann, 1973) that they drew on at the beginning of the communication course.

The diagnostic assessment provided initial evidence that, contrary to the expectations of our nine colleagues, all of whom are experienced instructors in engineering communication, on the first day of the communication course, the majority of students were able to recognize and articulate rhetorical and textual features of different genres, including the genre of the technical report. This observation supports the argument (e.g., Freedman, 1994, 2006) that explicit teaching of genre features-which is often done by showing students a genre model and then parsing it-may not be necessary. In fact, explicit teaching of the rhetorical and textual features of such models may override the tacit, deeper, and therefore more meaningful processing that occurs when students make sense of what they read on their own terms and in relation to what they know and observe. As Gee (2010) observed, genres are conventional ways of doing, and conventional ways are not explicitly learned; explicitly teaching genre features using a prototype, a model, may lead students to produce texts that are not "quite right" in every context except the one in which the prototype was taught.

Although most of our students had already developed awareness of different genres by the time they came to the communication course, their genre awareness was uneven. Some students clearly could have benefited from support (as was the case with the student in Wardle's 2007 study). In this regard, recent attempts to teach genre awareness rather than genre features (Devitt, 2004; Devitt, Reiff, \& Bawarshi, 2004; Downs \& Wardle, 2007; Wardle, 2007 ) in order to establish "mediating links between familiar and unfamiliar generic contexts" (Prince, 1989, p. 730) deserve further investigation.

Had we not probed our students' antecedent genre knowledge on the first day of our course, we might have erred in teaching them what they already knew - that is, teaching below their actual developmental level-and, as a result, reinforced their initial perception that the course offered them nothing new. The benefit of this diagnostic approach was that it allowed us to identify individual strengths and weaknesses and to target our pedagogy (Fox, 2008; Fox \& Hartwick, in press) accordingly.

This article illustrates how RGS can continue to inform writing pedagogy in important ways (cf. Artemeva, 2005, 2008, 2009; Coe, 2002; Downs \& Wardle, 2007). If situated performance serves as a primary vehicle for genre acquisition (cf. Dias et al., 1999; Freedman, 1994; Gee, 2010), then the RGS-based diagnostic assessment appears to provide a potential first step toward the 
"savvy" learning (Schryer, Lingard, \& Spafford, 2003) of discipline- and domainspecific genres. In other words, this assessment may lead both to awareness, by comprehending the exigencies of the rhetorical situation (cf. Dannels, 2009; Miller, 1994), and to performance in the appropriate genre. In addition to helping us probe our students' understandings of genre, the diagnostic assessment helped us to probe our own understandings as instructors; it stimulated selfreflection and increased its continuity, and supported student acquisition of engineering genres.

Finally, in the illustrative example of our diagnostic assessment, not all of the 11 students who had written technical reports in the past were able to perform in this genre (see Table 3). Only seven of the 11 students wrote an appropriate technical report passage. Thus, even after "having written" (Freedman, 1994, p. 206) in the genre, some students might still not be able to perform appropriately in this genre. Production may therefore be a necessary but insufficient precondition for genre competence. What other "genre ingredients" (Artemeva, 2005), or preconditions, are critical to the development of disciplineand domain-specific genre competence? Further research, which clearly does not have to be limited to engineering genres, is required to address this question.

\section{Notes}

${ }^{1}$. Those students who had not taken the phased-out requirement to write a summer engineering report (Freedman \& Artemeva, 1998) and those who had not performed satisfactorily on that report were required to take the new communication course. This resulted in several 2 nd and 3 rd year students taking the course.

${ }^{2}$. Please note that several Web sites that served as sources for the assessment passages are no longer functional.

3 . More recently, Swain has preferred the notion of dialogue rather than output, implying coconstruction in production (see Fox, 2004a, p. 247; Swain, 2000).

${ }^{4}$. The particular structure was a complex sentence without a conjunction (Bakhtin, 1997), translated as parataxis in Bakhtin (2004).

\section{References}

Artemeva, N. (1998). Writing consultant as cultural interpreter: Bridging different cultural perspectives on the genre of periodic engineering report. Technical Communication Quarterly, 7, 285-299.

Artemeva, N. (2000). Revising a research article: Dialogic negotiation. In P. Dias \& A. Paré (Eds.), Transitions: Writing in academic and workplace settings. (pp. 183-197). Cresskill, NJ: Hampton. 
Artemeva, N. (2005). A time to speak, a time to act: A rhetorical genre analysis of a novice engineer's calculated risk-taking. Journal of Business and Technical Communication, 19, 389-421.

Artemeva, N. (2008). Toward a unified theory social of genre learning. Journal of Business and Technical Communication 22, 160-185. doi: $10.1177 / 1050651907311925$

Artemeva, N. (2009). Stories of becoming: A study of novice engineers learning genres of their profession. In C. Bazerman, A. Bonini, \& D. Figueiredo (Eds.), Genre in a changing world. Fort Collins, CO: WAC Clearinghouse and Parlor Press. Retrieved from http://wac.colostate.edu/books/genre/

Artemeva, N. (in press). "An engrained part of my career": The formation of a knowledge worker in the dual space of engineering knowledge and rhetorical process. In D. Starke-Meyerring, A. Paré, N. Artemeva, M. Horne, \& L. Yousoubova (Eds.), Writing (in) the knowledge society. West Lafayette, IN: Parlor Press; Fort Collins, CO: WAC Clearinghouse.

Artemeva, N., \& Fox, J. (1999). Through the looking glass: Identifying causes of the Alice-syndrome in undergraduate engineering writers. Inkshed. Newsletter of the Canadian Association for the Study of Language and Learning, 17(2), 8 -11.

Artemeva, N., \& Freedman, A. (2001). "Just the boys playing on computers": An activity theory analysis of differences in the cultures of two engineering firms. Journal of Business and Technical Writing, 15, 164 - 194.

Artemeva, N., \& Freedman, A. (2006). Rhetorical genre studies and beyond. Winnipeg, Canada: Inkshed.

Artemeva, N., Logie, S., \& St.Martin, J. (1999). From page to stage: How theories of genre and situated learning help introduce engineering students to discipline-specific communication. Technical Communication Quarterly, 8, 301-316.

Bachman, L. (1990). Fundamental considerations in language testing. Oxford, UK: Oxford University Press.

Bachman, L., \& Palmer, A. (1996). Language testing in practice. Oxford, UK: Oxford University Press.

Bakhtin, M. M. (1997). Voprosi stilistiki na urokah russkogo yazika $v$ sredney shkole [Problems of stylistics in the Russian language classroom in secondary school.] In M. M. Bakhtin, Collected works, (Vol. 5, pp. 141-156). Moscow: Russkie slovary. (Original work published in 1994) 
Bakhtin, M. M. (2004). Dialogic origin and dialogic pedagogy of grammar: Stylistics in teaching Russian language in secondary school. Journal of Russian and East European Psychology, 42(6), 12-49.

Bawarshi, A. (2000). The genre function. College English, 62, 335-360.

Bawarshi, A., \& Reiff, M. J. (2009, March). Tracing discursive resources: The influence of prior genre knowledge. Paper presented at the Sixtieth Annual Convention of the Conference on College Composition and Communication, San Francisco, CA.

Bawarshi, A., \& Reiff, M. J. (in press). Genre: An introduction to history, theory, research, and pedagogy. Fort Collins, CO: WAC Clearinghouse and Parlor Press.

Berkenkotter, C., \& Huckin, T. N. (1995). Genre knowledge in disciplinary communication: Cognition/culture/power. (pp. 4-25). Hillsdale, NJ: Erlbaum.

Campbell, K. K., \& Jamieson, K. H. (Eds.). (1978). Form and genre: Shaping rhetorical action. Falls Church, VA: Speech Communication Association.

Challenger shuttle. (n. d. a). In Microsoft Encarta On-line. Retrieved from http://uk.encarta.msn.com/encnet/refpages/artcenter.aspx

Challenger shuttle. (n. d. b). Retrieved from http://news.bbc.co.uk/

Clarke, S. (1998). Targeting assessment in the primary classroom. Bristol, UK: Hodder \& Stoughton.

Coe, R. M. (2002). The new rhetoric of genre: Writing political briefs. In A. M. John (Ed.), Genre in the classroom: Multiple perspectives. (pp. 197 - 207). Mahwah, NJ: Erlbaum.

Coe, R. M., \& Freedman, A. (1998). Genre theory: Australian and North American approaches. In M. L. Kennedy (Ed.), Theorizing composition: A critical sourcebook of theory and scholarship in contemporary composition studies (pp. 136-147). Westport, CT: Greenwood Press.

Dannels, D. P. (2009). Features of success in engineering design presentations: A call for relational genre knowledge. Journal of Business and Technical Communication, 23, 399-427. doi: 10.1177/1050651909338790

Dean, D. (2008). Genre theory: Teaching, writing, and being. Urbana, IL: National Council of Teachers of English.

Devitt, A. J. (1991). Intertextuality in tax accounting: Generic, referential, and functional. In C. Bazerman \& J. Paradis (Eds.), Textual dynamics of the professions: Historical and contemporary studies of writing in 
professional communities (pp. 336-356). Madison: University of Wisconsin Press.

Devitt, A. J. (2004). Writing genres: Rhetorical philosophy \& theory. Carbondale: Southern Illinois University Press.

Devitt, A. J. (2009). Re-fusing form in genre study. In J. Giltrow \& D. Stein (Eds.), Genres in the Internet (pp. 27-47). Amsterdam: Benjamins.

Devitt, A., Reiff, M. J., \& Bawarshi, A. (2004). Scenes of writing: Strategies for composing with genres. (pp. 93-94). New York: Pearson/Longman.

Dias, P., Freedman, A., Medway, P., \& Paré, A. (1999). Worlds apart: Acting and writing in academic and workplace contexts. Mahwah, NJ: Erlbaum.

Dochy, F., Segers, M., \& Buehl, M. M. (1999). The relation between assessment practices and outcomes of studies: The case of research on prior knowledge. Review of Educational Research, 69, 145-186. doi: 10.3102/00346543069002145

Downs, D., \& Wardle, E. (2007). Teaching about writing, righting misconceptions: $(\mathrm{Re})$ envisioning "First-Year Composition" as "Introduction to Writing Studies." College Composition and Communication, 58, 552-584.

Fahnestock, J. (1993). Genre and rhetorical craft. Research in the Teaching of English, 27, 265-271.

Ford, J. D. (2004). Knowledge transfer across disciplines: Tracking rhetorical strategies from a technical communication classroom to an engineering classroom. IEEE Transactions on Professional Communication, 47, 301315. doi: 10.1109/TPC.2004.840486

Fox, J. (2000). Testing manual: CAEL assessment. Ottawa, Canada: Carleton University Press.

Fox, J. (2001). It's all about meaning: $L 2$ test validation in and through the landscape of an evolving construct. Unpublished doctoral dissertation, McGill University, Montreal, Quebec, Canada.

Fox, J. (2003). From products to process: An ecological approach to bias detection. International Journal of Testing, 3 (1), 21-48.

Fox, J. (2004a). "Biasing for the best" in language testing and learning: An interview with Merrill Swain. Language Assessment Quarterly, 1, 235-251.

Fox, J. (2004b). Test decisions over time: Tracking validity. Language Testing, $21,437-465$. 
Fox, J. (2008). Moderating top-down policy impact and supporting EAP curricular renewal: Exploring the potential of diagnostic assessment. Journal of English for Academic Purposes, 8, 26-42.

Fox, J. \& Hartwick, P. (in press). Taking a diagnostic turn: Reinventing the portfolio in EAP classrooms. In D. Tsagari \& I. Csepe (Eds.). Classroom-based language assessment. Frankfurt: Peter Lang.

Freadman, A. (1994). Anyone for tennis? In A. Freedman \& P. Medway (Eds.), Genre and the new rhetoric (pp. 43-66). London: Taylor and Francis. (Original work published 1987)

Freadman, A. (2002). Uptake. In R. Coe, L. Lingard, \& T. Teslenko (Eds.), The rhetoric and ideology of genre (pp. 39-53). Cresskill, NJ: Hampton Press.

Freedman, A. (1987). Learning to write again: Discipline-specific writing at university. Carleton Papers in Applied Language Studies, 4, 95-115.

Freedman, A. (1993a). Show and tell? The role of explicit teaching in the learning of new genres. Research in the Teaching of English, 27, 222-251.

Freedman, A. (1993b). Situating genre: A rejoinder. Research in the Teaching of English, 27, 272-281.

Freedman, A. (1994). "Do as I say": The relationship between teaching and learning new genres. In A. Freedman \& P. Medway (Eds.), Genre and the new rhetoric (pp. 191-210). London: Taylor \& Francis.

Freedman, A. (1997). Situating "genre" and situated genres: Understanding student writing from a genre perspective. In W. Bishop \& H. Ostrom (Eds.), Genres and writing: Issues, arguments, alternatives (pp. 179-190).

Portsmouth NH: Heinemann, Boynton/Cook.

Freedman, A. (2006). Interaction between theory and research: RGS and a study of students and professionals working in computers. In N. Artemeva \& A. Freedman (Eds.), Rhetorical genre studies and beyond. (pp. 101120).Winnipeg, Canada: Inkshed.

Freedman, A., \& Artemeva, N. (1998). Learning to teach writing to engineers. Technostyle, 14(1), 1-20.

Freedman, A., \& Medway, P. (Eds.). (1994). Genre and the new rhetoric. London: Taylor \& Francis.

Gee, J. P. (2008). Learning and situated domains: A social and situated account. In M. Prinsloo \& M. Baynham (Eds.), Literacies, global and local. (pp. 137149). Amsterdam: Benjamins.

Gee, J. P. (2010, January 22). Language, literacy, and learning in a digital age. Paper presented at the School of Linguistic and Language Studies Guest Speaker Seminar, Carleton University, Ottawa, Canada. 
Geisler, C. (1994). Academic literacy and the nature of expertise: Reading, writing, and knowing in academic philosophy. Hillsdale, NJ: LEA.

Giltrow, J., \& Valiquette, M. (1994). Genres and knowledge: Students writing in the disciplines. In A. Freedman \& P. Medway (Eds.), Learning and teaching genre. (pp. 47-62). Portsmouth, NH: Heinemann.

Haas, C. (1994). Learning to read biology: One student's rhetorical development. Written Communication, 11, 43-84.

Hanks, W. F. (1987). Discourse genres in a theory of practice. American Ethnologist, 14, 668-692.

Heeks, A. (n. d.). Challenger space shuttle. Retrieved from http://cems.alfred.edu/students98/heeksab/challenger\%20paper.html

Hengst, J. A., \& Miller, P.J. (1999). The heterogeneity of discourse genres: Implications for development. World Englishes, 18, 325-341.

Honig, S. (2010). What do children write in science? A study of the genre set in a primary science classroom. Written Communication, 27, 87-119.

Hoover, J. D. (1989). Big boys don't cry: The values constraint in apologia. Southern Communication Journal, 54, 235-252.

Hyland, K. (2007). Genre pedagogy: Language, literacy and L2 writing instruction. Journal of Second Language Writing, 16, 148-164.

Jamieson Hall, K. M. (1973). Generic constraints and rhetorical situation. Philosophy and Rhetoric, 6, 162-170.

Jamieson, K. M. (1975). Antecedent genre as rhetorical constraint. Quarterly Journal of Speech, 61, 406-415.

Katz, S. M. (1998). The dynamics of writing review: Opportunities for growth and change in the workplace. Stamford, CT: Ablex.

Lave, J., \& Wenger, E. (1991). Situated learning: Legitimate Peripheral Participation. Cambridge, UK: Cambridge University Press.

Miller, C. (1994). Genre as social action. In A. Freedman \& P. Medway (Eds.), Genre and the new rhetoric (pp. 23-42). London: Taylor \& Francis. (Original work published 1984)

Paré, A., \& Smart, G. (1994). Observing genres in action: Towards a research Methodology. In A. Freedman and P. Medway (Eds.), Genre and the new rhetoric (pp. 146-155). London: Taylor \& Francis.

Perkins, D. N, \& Salomon, G. (n. d). The science and art of transfer. Retrieved from http://learnweb.harvard.edu/andes/thinking/docs/trancost.pdf 
Polanyi, M. (1997). Tacit dimension. In L. Prusak (Ed.), Knowledge in organizations (pp. 135-146). Newton, MA: Butterworth-Heinemann. (Original work published 1966)

Prince, M. B. (1989). Literacy and genre: Towards a pedagogy of mediation. College English, 51, 730-749.

Rehling, L. (2010). Foregrounding positive problem-solving teamwork: Awareness and assessment exercises for the first class and beyond. Journal of Business and Technical Communication, 24(2), 234-244. doi: $10.1177 / 1050651909353546$

Report of the presidential commission on the space shuttle Challenger accident. (1986). Retrieved from http://science.ksc.nasa.gov/shuttle/missions/51l/docs/rogers-commission/table-of-contents.html

Rounsaville, A., Goldberg, R., \& Bawarshi, A. (2008). From incomes to outcomes: FYW students' prior genre knowledge, meta-Cognition, and the question of transfer. WPA: Writing Program Administration 32 (1), 97-112.

Russell, D. (1997). Rethinking genre in school and society: An activity theory analysis. Written Communication, 14, 504-554.

Russell, D. (2010). Writing in multiple contexts: Vygotskian CHAT meets the phenomenology of genre. In C. Bazerman, R. Krut, K. Lunsford, S. McLeod, S. Null, P. Rogers, \& A. Stansell (Eds.), Traditions of writing research. (pp. 353-364). New York: Routledge.

Ryle, G. (1949). The concept of mind. London, England: Hutchinson \& Company.

Scanlon, L., Rowling, L., \& Weber, Z. (2007). "You don't have like an identity . . . you are just lost in a crowd": Forming a student identity in the first-year transition to university. Journal of Youth Studies, 10, 223-241. doi: $10.1080 / 13676260600983684$

Schryer, C. (1993). Records as genre. Written communication, 10, 200-234.

Schryer, C. F., Lingard, L., \& Spafford, M. (2003). Structure and agency in medical case presentations. In C. Bazerman \& D. Russell (Eds.), Writing selves/writing societies: Research from activity perspectives. Fort Collins, CO: WAC Clearinghouse and Mind, Culture, and Activity. Retrieved from http://wac.colostate.edu/books/selves_societies/

Schutz, A., \& Luckmann, T. (1973). Structures of the Life-World. Evanston, IL: Northwestern University Press.

Smart, G., \& Gilbert J., (2009). Writers developing "genre capability" in the world of banking: The perspectives and praxis of the writing coach. Paper 
presented at the 5th International Symposium on Genre Studies, Caxias do Sul, Brazil.

Swain, M. (1985). Communicative competence: Some roles of comprehensible input and comprehensible output in its development. In S. Gass \& C. Madden (Eds.), Input in second language acquisition. (pp. 235-253). Rowley, MA: Newbury House.

Swain, M. (2000). The output hypothesis and beyond: Mediating acquisition through collaborative dialogue. In J. P. Lantolf (Ed.), Sociocultural theory and second language learning (pp. 97-114). Oxford: Oxford University Press.

Swain, M., \& Lapkin, S. (1995). Problems in output and the cognitive problems they generate: A step towards second language learning. Applied Linguistics, 16, $371-391$.

Tobias, S. (1994). Interest, prior knowledge, and learning. Review of Educational Research, 64(1), 37-54.

Tuomi-Gröhn, T., \& Engeström, Y. (Eds.). (2003). Between school and work: New perspectives on transfer and boundary-crossing. Boston: Pergamon.

UT-UW prior genre study. (2007-2008). Retrieved from http://utuwpriorgenre.blogspot.com/

Vygotsky, L. S. (1978). Mind in society: The development of higher psychological processes. M. Cole, John-Steiner, V., S. Scribner, \& E. Souberman (Eds.). Cambridge, MA: Harvard University Press.

Vygotsky, L. S. (2003). Umstvennoe razvities detey v processe obuchenia [Mental development of children during education]. Psikhologia razvitia rebenka [Psychological development of a child] (pp. 327-505). Moscow, Russia: EKSMO. (Original work published 1935)

Wardle, E. (2007). Understanding "transfer" from FYC: Preliminary results of a longitudinal study. Writing Program Administration, 31(1-2), 65-85.

Wenger, E. (1998). Communities of practice: Learning, meaning, and identity. Cambridge, UK: Cambridge University Press.

Williams, J. M., \& Colomb, G. G. (1993). The case for explicit teaching: Why what you don't know won't help you. Research in the Teaching of English, 27, 252-264.

Winsor, D. (1995). Writing like an engineer: A rhetorical education. Mahwah: Erlbaum.

Zachry, M., \& Thralls, C. (Eds.). (2007). Communicative practices in workplaces and the professions. Amityville, NY: Baywood. 
Canadian Journal for Studies in Discourse and Writing 24.1 (2012)

(C) Canadian Association for the Study of Discourse and Writing

ISSN: 0712-4627 


\section{Appendix A}

A Sample Diagnostic Genre Assessment: The Challenger Shuttle Disaster

\section{Purpose}

This assessment has two purposes:

1. To obtain a preliminary assessment of students' communication skills.

2. To allow the instructor to provide early individual feedback to students.

\section{Assessment}

1. The instructor will provide written feedback to each student on his/her test.

2. The instructor will provide a mark; however, it will not be incorporated into the final grade calculation.

\section{General Instructions}

The test must be written in pen.

\section{Tasks}

This test has two tasks.

\section{Task 1}

Read the passages provided. Where do you think these passages are from (e.g. advertisement, magazine, newspaper, technical report, student essay, encyclopedia, textbook, scholarly publication, set of instructions, book review, etc.)? In the space provided after each passage, indicate its source type/s and briefly explain what helped you identify the source.

\section{Task 2}

Read the passages carefully. Using key information provided in the passages, write about the Challenger Shuttle Disaster in a way that you think may be appropriate for a technical report. Write in your own words as opposed to copying directly from the passages.

\section{Passages for Tasks 1 and 2}

\section{Passage 1}

Challenger Disaster, accident that destroyed the United States space shuttle Challenger during takeoff on January 28,1986 . All seven crew members died. A faulty "O-ring" seal failed in the solid-fuel rocket on the shuttle's right side.

Flames escaped through the failed seal. The flames burned through the shuttle's 
external fuel tank and a support attaching the rocket to the tank. The rocket broke loose and pierced the tank. Liquid hydrogen and liquid oxygen fuels ignited, tearing the shuttle apart. The shuttle launch program was not resumed until designers made modifications and National Aeronautics and Space Administration (NASA) management implemented stricter regulations regarding quality control and safety. Shuttle missions resumed on September 28, 1988, with the flight of the shuttle Discovery.

Source type(s):

Why:

\section{Passage 2}

Some engineers at Morton Thiokol, the contractor responsible for the solid rocket boosters, believed that the joint the O-ring sealed was therefore unsafe, but they were unable to convince personnel at NASA or even their own managers of the joint's weakness in the weeks before the launch. One factor in the failed communication seems to have been that managers at NASA looked at the 24 past shuttle launches as evidence of the joint's safety, seeing those data as more relevant than the numbers produced in the test lab. In contrast, attending to the test data and not to the launch history led the engineers working on the joint to conclude that the joint was faulty. However, they apparently believed that if they simply sent their data to managers, the managers would automatically be convinced by these data in the same way the engineers themselves had been (Herndl, Fennel, \& Miller, 1991; Winsor, 1988, 1990a). Thus, in this situation, which was complicated in the way reality almost always is, the relevance of different data was unclear, and the meaning of any of the data required interpretation. The existence of the data alone was insufficient to create knowledge.

Source type(s):

Why:

\section{Passage 3}

Both NASA and Morton Thiokol, the manufacturers of the Solid Rocket Boosters, knew that the O-rings, the two rubber rings sealing the segments of the boosters, were prone to erosion. The metal bowed out on launch and hot gases could escape if the rubber did not seal the joint properly.

A fraught eve of launch teleconference involving NASA and Morton Thiokol highlighted the problem. The predicted
The Rogers Commission 256-page report described a failure in management, which even today is used as a model in business schools of how not to make a decision. Boisjoly-one of the most vocal of the Thiokol engineers--says that his recommendation not to launch was unprecedented, at least within Morton Thiokol, and this should have immediately been accepted by NASA. 
launch temperature, 29 degrees

Fahrenheit, was 24 degrees below their

coldest launch to date.

Source type(s):

Why:

\section{Passage 4}

\subsection{THE CAUSE OF THE ACCIDENT}

\subsection{FINDINGS}

16. The leak was again clearly evident as a flame at approximately 58 seconds into the flight. It is possible that the leak was continuous but unobservable or non-existent in portions of the intervening period. It is possible in either case that thrust vectoring and normal vehicle response to wind shear as well as planned maneuvers reinitiated or magnified the leakage from a degraded seal in the period preceding the observed flames. The estimated position of the flame, centered at a point 307 degrees around the circumference of the aft field joint, was confirmed by the recovery of two fragments of the right Solid Rocket Booster. ...

\subsection{CONCLUSION}

In view of the findings, the Commission concluded that the cause of the Challenger accident was the failure of the pressure seal in the aft field joint of the right Solid Rocket Booster. The failure was due to a faulty design unacceptably sensitive to a number of factors. These factors were the effects of temperature, physical dimensions, the character of materials, the effects of reusability, processing and the reaction of the joint to dynamic loading.

Source type(s):

Why:

\section{Passage 5}

Introduction

The skies were clear and the sun shone on the cold freezing morning of January 28,1986 . Kennedy Space Center in Florida was busy preparing the launch of the 25th space shuttle into space. Mission 51-L, the 10th flight of Orbiter Challenger. This was one of the most publicized launches because it was the first time that a civilian, a school teacher, was going into space. The launch of Challenger had been delayed five times due to bad weather, January 28 was the coldest day that NASA had ever launched a shuttle. The time had come, at 11:38 AM Eastern 
Standard Time, Challenger left Pad 39B at Kennedy. Seventy three seconds into flight, the Orbiter Challenger exploded, killing all seven of its crew.

Source type(s):

Why: 


\section{Appendix B}

\section{Assessment Reflection Form}

1. Had you seen, read and/or written a technical report before you were asked to write "what you thought might be appropriate for a technical report" in the Preliminary Assessment? Please circle the appropriate answer:

Yes No

If you answered Yes, go to question 2.

If you answered No, go to question 3 .

2. Please explain under what circumstances you saw, read, and/or wrote a technical report.

3. Please explain what made you write your response to Task 2 of the Preliminary Assessment ("write about the Challenger Shuttle Disaster in a way that you think may be appropriate for a technical report') the way you wrote it. 


\section{Bios}

Natasha Artemeva is an associate professor in the School of Linguistics and Language Studies at Carleton University. She has advanced degrees in engineering, applied language studies, and education. She has taught and coordinated engineering communication courses and courses in writing studies. She is the winner of the 2007 CCCC Outstanding Dissertation Award in Technical Communication and a coeditor (with Aviva Freedman) of Rhetorical Genre Studies and Beyond (Inkshed, 2006).

Janna Fox is an associate professor in the School of Linguistics and Language Studies at Carleton University. She teaches courses in language assessment, curriculum, and research methods and directs the Language Assessment and Testing Research Unit, which engages in research relating to test development, models of assessment, educational reform, and program evaluation.

\section{Acknowledgments}

We gratefully acknowledge financial support provided by the Social Sciences and Humanities Research Council of Canada through a standard research grant. We thank our colleagues and students for participating in the study, and in particular, Susan Logie for helping us read student assessment papers and Futoshi (Tosh) Tachino for providing constructive feedback on an earlier version of the article. Our gratitude goes to David Russell and two anonymous reviewers for their valuable comments and to Lori J. Peterson for thorough editing. 